\title{
Intake, nutrients digestibility and nitrogen balance of elephant grass silages with mango by-product addition ${ }^{1}$
}

\section{Margareth Maria Teles Rêgo ${ }^{2}$, José Neuman Miranda Neiva ${ }^{3}$, Aníbal Coutinho do Rêgo ${ }^{4}$, Magno José Duarte Cândido ${ }^{5}$, Arnaud Azevêdo Alves ${ }^{6}$, Raimundo Nonato Braga Lôbo ${ }^{7}$}

\author{
${ }^{1}$ Pesquisa financiada pelo CNPq e FUNCAP. \\ 2 Programa de Pós-Graduação em Zootecnia da Universidade Federal do Ceará. \\ ${ }^{3}$ Universidade Federal do Tocantins. Bolsista do CNPq. \\ ${ }^{4}$ Mestrando da Universidade Federal de Lavras. \\ ${ }^{5}$ Universidade Federal do Ceará. \\ 6 Universidade Federal do Piauí. \\ ${ }^{7}$ Embrapa-Caprinos.
}

\begin{abstract}
The objective of this study was to evaluate the nutritive value of elephant grass silages with increasing levels of dried mango by-product (DMB). Five addition levels were studied (0, 4, 8, 12 and 16\%) using 20 rams, in a randomized complete design with five treatments (addition levels) and four replications. Dry matter (DM), organic matter (OM), crude protein (CP), neutral detergent fiber (NDF), acid detergent fiber (ADF), ether extract (EE), total carbohydrates (TC), nonfibrous carbohydrates (NFC) intake and digestibility were evaluated, as well as the total digestible nutrients (TDN) and the silage nitrogen balance (NB). Mango by-product addition did not influence the DM, CP and TC intakes, the TDN level or the OM, CT and NFC digestibilities. On the other hand, DMB addition reduced the NDF and the ADF intakes, as well as the DM, CP, NDF and ADF digestibilities, and the NB of the silages. There was also a increasing linear effect of DMB addition on the EE and NFC intakes, and on EE digestibility. The elephant grass silage with DMB by-product may not be used as a single feed to ruminants because it reduces the NDF and the ADF intakes and the DM, CP, NDF and ADF digestibilities, as well as the nitrogen balance.
\end{abstract}

Key Words: ensiling, Mangifera indica, nutritive value, sheep

\section{Consumo, digestibilidade de nutrientes e balanço de nitrogênio de silagens de capim-elefante contendo subproduto de manga}

\begin{abstract}
RESUMO - Esta pesquisa foi realizada objetivando avaliar o valor nutritivo de silagens de capim-elefante contendo níveis crescentes de subproduto do processamento de manga desidratado. Foram estudados cinco níveis de adição (0,0; 4,$0 ; 8,0 ; 12$ e 16,0\%) utilizando-se 20 ovinos, machos não-castrados, em delineamento experimental inteiramente casualizado com cinco tratamentos (níveis de adição) e quatro repetições. Foram avaliados os consumos e as digestibilidades aparentes dos nutrientes, além do valor de nutrientes digestíveis totais (NDT) e do balanço de nitrogênio das silagens. A adição de resíduo do processamento de manga não influenciou os consumos de MS, PB, carboidratos totais e NDT nem as digestibilidades de matéria orgânica (MO), carboidratos totais (CT) e carboidratos não-fibrosos (CNF) e o teor de NDT das silagens. A inclusão do resíduo na ensilagem de capim-elefante ocasionou reduções nos consumos de FDN e FDA; na digestibilidade da MS, PB, FDN e FDA e no balanço de nitrogênio. A inclusão do subproduto promoveu também efeito linear crescente nos consumos de EE e CNF e na digestibilidade do EE das silagens. A silagem de capimelefante com subproduto do processamento de manga não deve ser utilizada como única fonte de alimento para ruminantes, pois reduz os consumos de FDN e FDA e as digestibilidades da MS, PB, FDN e FDA, além do balanço de nitrogênio.
\end{abstract}

Palavras-chave: ensilagem, Mangifera indica, ovinos, valor nutritivo

\section{Introduction}

Forage conservation in the form of silage has been used traditionally by producers as a way of meeting foodstuff demand, especially in the dry period of the year (Vilela et al., 2002). Among the tropical grasses, elephant grass (Pennisetum purpureum Schum.), much used in meadows for cutting, is important as forage for ensilage, 
because of its high production per area and good nutritive value. According to Gomide (1997), this occurs when the plant presents 50\% leaf and 50\% stem.

Although it has higher production and reasonable quality, according to various authors (Lavezzo, 1985; Nússio et al., 2002; Vilela \& Carneiro, 2002) excess moisture at the ideal cutting time is the main limiting factor for ensilage that according to Wilkinson (1983) favors low osmotic pressure that leads to the development of the Clostridium genus bacteria contributing to significant losses in silage quality and reduced palatability and intake.

To produce good quality elephant grass silage, techniques are needed at ensilage, such as wilting and using additives to raise the dry matter content, improve the fermentation process, prevent secondary fermentations, improve lactic acid production and raise the nutritive value (Vilela \& Carneiro, 2002).

Various agroindustrial by-products have been used as elephant grass silage additives, such as orange pulp, that promoted better fermentation and raised the nutritive value of the silage (Faria et al., 1972); passion fruit by-product, that in addition to improving the fermentation process, increased the dry matter (DM), crude protein (CP) and neutral detergent fiber (NDF) intake and digestibility (Reis et al., 2000); pineapple by-product, that improved DM intake (Ferreira et al., 2009); coffee hulls, that increased the DM contents but increased the NDF and acid detergent insoluble nitrogen (NIDA) and reduced DM digestibility (Bernardino et al., 2005).

Mango, after industrialization to manufacture pulps and juices, generates several by-products (skins, stones and scrap fruits) that can be used in animal feeding or as additives to elephant grass silage. Thus the objective of this study was to assess the nutritive values of elephant grass silages containing increasing levels of by-product from processing dried mango.

\section{Material and Methods}

The experiment was carried out at the Núcleo de Pesquisa em Forragicultura of Departamento de Zootecnia of Universidade Federal do Ceará. The municipality of Fortaleza is in the coastal zone at 15.49 m altitude, $3^{\circ} 43^{\prime} 02^{\prime \prime}$ Latitude South and $38^{\circ} 32^{\prime} 35^{\prime \prime}$ Longitude west.

Five levels of dried mango (Mangifera indica L.) byproduct addition were studied: 0, 4, 8, 12 and $16 \%$ in relation to the natural matter of the elephant grass (Pennisetum purpureum, Schum). Elephant grass was used to make the silages from a field already established in the Vale do Curú, in Fazenda Experimental, in Pentecoste, Ceará, belonging to the Universidade Federal do Ceará. After the standardization cut, the area was mulched with $50 \mathrm{~kg} / \mathrm{ha} \mathrm{N}$ and $40 \mathrm{~kg} / \mathrm{ha} \mathrm{K}_{2} \mathrm{O}$ in the form of urea and potassium chloride, respectively. The grass was cut manually at 70 days growth and was later processed in a stationary forage chopper, adjusted to cut medium sized particles between 1 and $2 \mathrm{~cm}$.

The mango by-product used in the experiment came from juice manufacture and was dried to 13 and $16 \%$ moisture. It was dried in the sun, turning the material over three times a day and piling it up at night, when it was covered with canvas to prevent moisture accumulation.

At ensilage, the elephant grass presented $19.43 \%$ dry matter (DM), $87.81 \%$ organic matter (OM), 5.39\% crude protein (CP), 77.41\% neutral detergent fiber (NDF), 48.04\% acid detergent fiber (ADF), 29.37\% hemicellulose, 3.78\% ether extract (EE), 78.64\% total carbohydrates (TC) 1.23\% nonfibrous carbohydrate (NFC), 45.38\% NIDN and $14.89 \%$ NIDA. The mango by-product presented $94.60 \%$ DM, 94.3\% OM, 6.09\% CP, 61.20\% NDF, 35.15\% ADF, 26.05\% hemicellulose, 5.76\% EE, 82.49\% total carbohydrates, 21.29\% NFC, 55.87\% NIDN (\% total N)) and 20.60\% NIDA (\% total $\mathrm{N}$ ), based on the DM (Table 1).

The experimental silos were $210 \mathrm{~L}$ plastic drums, in which $126 \mathrm{~kg}$ forage were placed so that a density of $600 \mathrm{~kg} / \mathrm{m}^{3}$ was reached. After weighing and homogenizing the elephant grass with mango by-product, the material was placed in the silo, compacted and then the silos were closed with plastic sheeting fastened with rubber straps.

Twenty intact rams, no defined breed, $18.33 \mathrm{~kg}$ average live weight, were used to assess the apparent digestibility of the silage in a randomized complete design with five treatments ( $0,4,8,12$ and $16.0 \%$ mango by-product added) and four replications, considering the animal to be the experimental unit. Silage was used from a single experimental silo for each animal. The animals were weighed at the start and the end of the experiment, wormed and a randomly distributed among the diets.

The animals were kept in individual metabolism cages, with urine and feces collectors and separators, with hods to supply food and the mineral mixture and drinkers, with water always available.

The experiment lasted for 17 days: 12 days to adapt the animals to the diets and the experimental environment and five days to assess the voluntary intake, nutrient apparent digestibility and nitrogen balance. The silages were supplied daily in two periods, in the morning (6:30 a.m. to 7:30 a.m.) and in the afternoon (3:30 p.m. to 4:30 p.m.), in a quantity calculated daily from the intake of the previous day so that there was approximately $15 \%$ leftovers. 
Table 1 - Chemical composition of the elephant Grass silages containing mango by-product

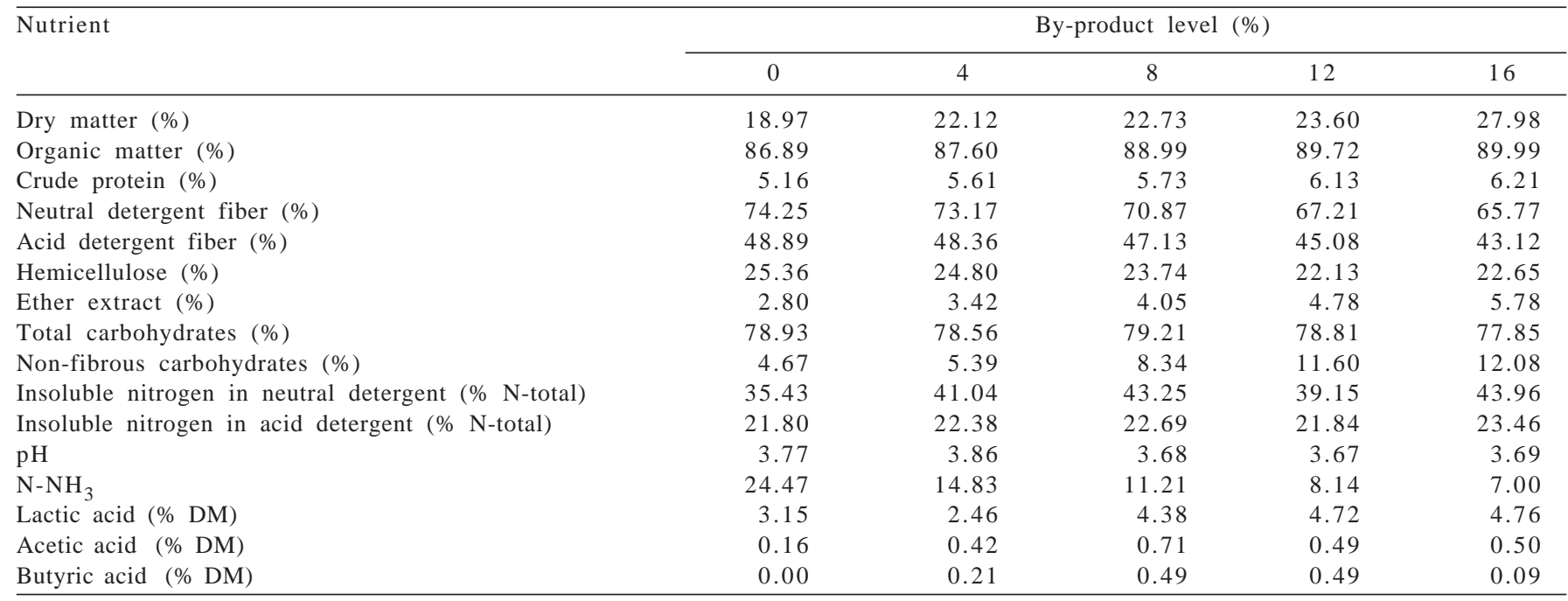

Silage samples (100 g) were obtained daily when the food was weighed throughout the data collection period. The samples were placed in plastic bags, labeled and stored in a freezer at $-10^{\circ} \mathrm{C}$. At the end of the experiment, the samples for each animal were thawed and homogenized, and a sample of approximately $300 \mathrm{~g}$ was removed that was processed (pre-dried) for later analyses.

The leftovers were weighed in the morning, before supplying new food. After weighing, an alquot of approximately $80 \mathrm{~g}$ was removed, following the same sampling procedure described for the offered foods.

The feces were collected during the assessment period and weighed in the morning, and samples of $10 \%$ of the total were removed and placed in a freezer at $-10^{\circ} \mathrm{C}$. At the end of the experiment, the samples for each animal were thawed and homogenized and approximately $30 \mathrm{~g}$ of the total from each animal were removed and were placed in plastic bags, identified and kept in a freezer at $-10^{\circ} \mathrm{C}$.

The urine was measured in the morning and afternoon, when aliquots of $10 \%$ of the total were removed and placed in a freezer at $-10^{\circ} \mathrm{C}$. Nitrogen losses through volatilization were prevented by adding $20 \mathrm{~mL}$ chlorine acid 1:1 to the urine collecting receptacles. In the food and feces samples, the following contents were determined: dry matter (DM), organic matter (OM), crude protein (CP), neutral detergent fiber (NDF), acid detergent fiber (ADF), ether extract (EE) and mineral matter (MM). The NFC contents were calculated by the difference between total carbohydrates and NDF, according to Hall (2001). The nitrogen content was determined in the urine samples by analyses carried out in the Laboratório de Nutrição Animal of Departamento de Zootecnia, in Fortaleza, following methodology described by Silva \& Queiroz (2002).
The intakes of DM, CP, NDF and ADF were estimated. The intakes of DM and CP were expressed in percentage live weight (\%PV) and $\mathrm{g} / \mathrm{UTM}\left(\mathrm{g} / \mathrm{PV}^{0.75}\right)$ and the NDF and ADF contents in percentage of live weight (LW). The coefficients of apparent digestibility of the DM and CP were determined on the true digestibility of the NDF and ADF, and the nitrogen balance (Silva \& Leão, 1979) and the total digestible nutrient (TDN) contents according to Sniffen et al. (1992).

Analysis of variance was carried out as approximation of the degree of fit of the data to the linear and quadratic models and regression analysis to assess the effect of the mango by-product levels using the SAS statistical package (2001). The most appropriate model for each variable was chosen based on the significance of the linear and quadratic coefficients, using the Student t-test at $1 \%$ and 5\% probability and the coefficient of determination.

Before these analyses, a study was made to verify whether the assumptions of normal distribution and homocedasticity of the data were met. The characteristics that did not meet these assumptions were transformed so the statistical analyses could proceed. The data obtained for NFC intake (\%PV, g/PV $\left.{ }^{0.75}\right)$ were transformed to $\log _{10}$ and the nitrogen balance $(\mathrm{BN})$ was transformed to $(\mathrm{BN}+1)$ for regression analysis.

\section{Results and Discussion}

The intakes of DM, OM and CP of the silages were not different $(\mathrm{P}<0.05)$ among the levels of mango by-product addition, whether in \% of the $\mathrm{PV}$ or $\mathrm{g} / \mathrm{PV}^{0.75}$ (Table 2). According to Van Soest (1994) increases in DM contents in silage to the $38 \%$ limit tend to favor intake. This tendency was not observed in the present study because although 
Table 2 - Nutrient intake in sheep fed elephant grass silages with various addition levels of mango by-product

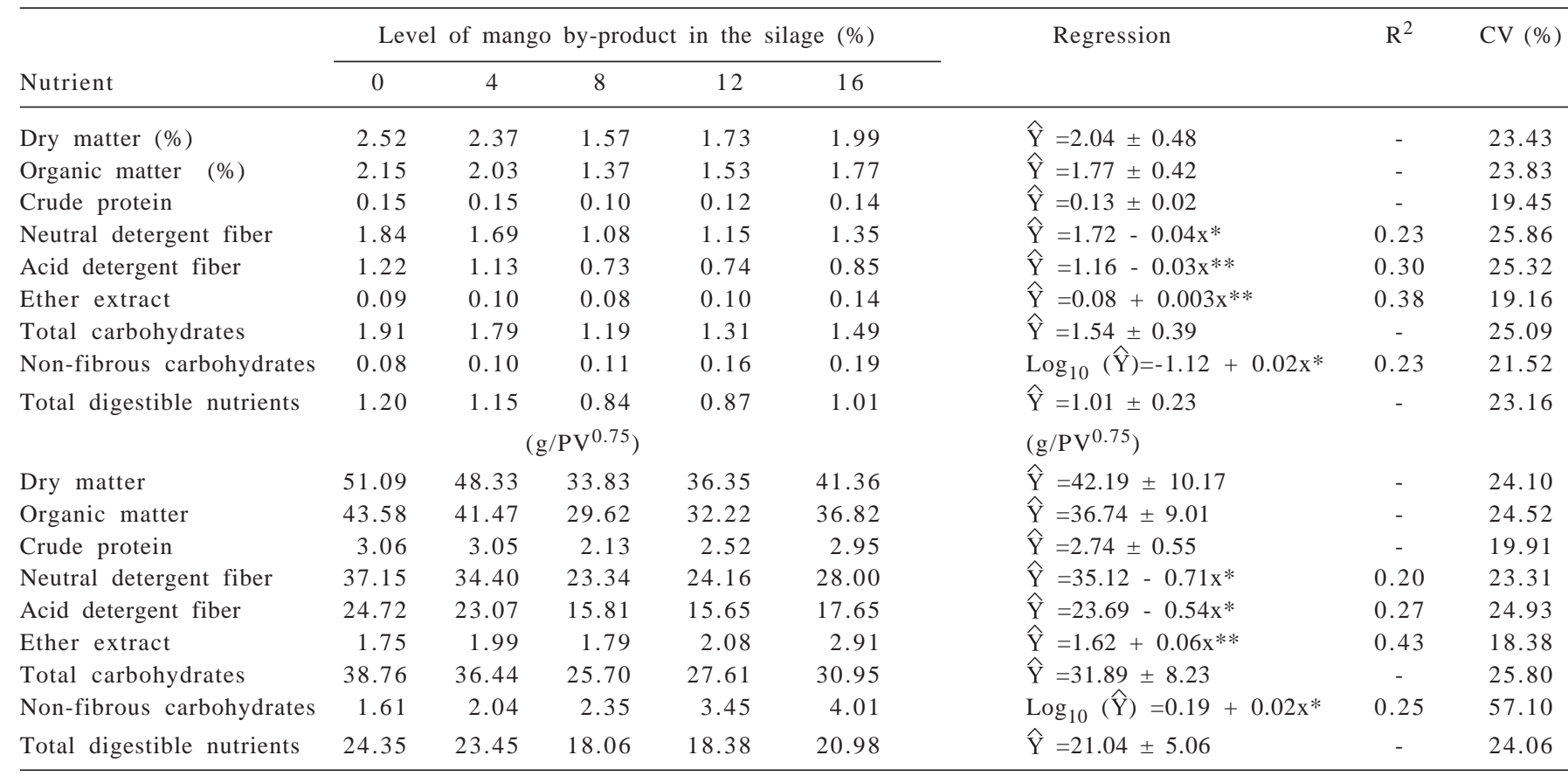

* $5 \%$ significance, $* * 1 \%$ significance.

$\mathrm{R}^{2}$ : coefficient of determination; CV: coefficient of variation.

the DM contents increased from $19.8 \%$ (0\% mango byproduct) to $27.02 \%$ (16\% level mango by-product) the DM intakes did not alter. However, the low CP content can inhibit voluntary forage intake. None of the silages in the present study presented the minimum level of 7\% CP required for good ruminal functioning (Silva \& Leão, 1979) (Table 1).

The EE contents in the silages reached levels that could inhibit forage intake. The levels rose from $0.8 \%$ in the untreated elephant grass silage to $5.78 \%$ in those with $16 \%$ mango by-product. This level exceeded the maximum limits recommended by Palmquist (1991) for bulk-based diets.

Other factors, such as high levels of acetic acid and ammoniacal nitrogen can reduce DM intake (Wilkins et al., 1971; Silveira et al., 1980), but in the silages studied, the small DM intake could not be explained by these parameters, because the silage presented a low acetic acid contents (0.16 to $0.71 \%$ ) and reduced ammonia nitrogen contents, that decreased from $21.88 \%$ in the untreated elephant grass silage to $7.24 \%$ in those with $16 \%$ mango by-product.

The results observed for CP intake were within the predicted, because as there were no significant alterations in the CP contents in the silages or in the DM intake, it was expected that there would be no increase in the values of this variable. Neiva et a. (2006), researched the addition of passionflower by-product to elephant grass silage and observed increase in the $\mathrm{CP}$ intake as a result of the greater $\mathrm{DM}$ intake and increase in the CP contents of the silage.
The NDF intake, in \% PV and $\mathrm{g} / \mathrm{PV}^{0.75}$, decreased linearly $(\mathrm{P}<0.01)$ with the inclusion of mango by-product in the elephant grass silage. At each $1 \%$ addition of byproduct to the silage, a reduction of 0.04 percentage point and $0.71 \mathrm{~g} / \mathrm{PV}^{0.75}$ was observed in the NDF intake expressed in $\% \mathrm{PV}$ and $\mathrm{g} / \mathrm{PV}^{0.75}$, respectively. For the ADF intake, however, for each $1 \%$ mango by-product there was a reduction $(\mathrm{P}<0.01)$ of 0.03 percentage point and $0.54 \mathrm{~g} / \mathrm{PV}^{0.75}$. This result was expected because as the DM intake was not altered and the NDF and ADF contents decreased with the inclusion of the mango by-product (Table 1) it was normal that the NDF and ADF intakes would decrease.

The EE intake increased linearly $(\mathrm{P}<0.01)$ with the inclusion of the mango by-product in the silage. For each $1 \%$ of mango by-product added to the elephant grass silage, there was an increase of 0.003 percentage point and $0.06 \mathrm{~g} / \mathrm{PV}^{0.75}$ in intake, a predictable result bearing in mind the increase in $\mathrm{EE}$ contents with the addition of the mango by-product.

The total carbohydrate intake did not differ $(\mathrm{P}<0.05)$ among the silages, with an average of $1.54 \%$ of the PV and $31.89 \mathrm{~g} / \mathrm{PV} 0.75$, that may have been associated to the similarity of the total carbohydrates contents of the silages and they therefore followed the same tendency observed for $\mathrm{CP}$ intake. Mango by-product inclusion raised $(\mathrm{P}<0.05)$ the NFC intake of the silage. For each $1 \%$ added, there was an increase of 0.006 percentage point compared to the live weight and $0.11 \mathrm{~g} / \mathrm{PV} 0.75$, a fact associated to the increase 
in the NFC contents with the addition of mango byproduct (Table 1 ).

The TDN intake did not alter $(\mathrm{P}<0.05)$ with the inclusion of mango by-product in the elephant grass silage, and presented an average of $1.01 \% \mathrm{PV}$ and $21.04 \mathrm{~g} / \mathrm{PV} 0.75$, that was explained by the fact that the TDN values in the silage were not altered with the addition of mango by-product to the silage. As the TDN in the silages did not alter with the addition of mango by-product this result was justifiable because the DM intake was similar among the silages.

The mango by-product levels had a linear effect $(\mathrm{P}<0.05)$ on the DM apparent digestibility (Table 3) that decreased 0.47 percentage point for each $1 \%$ mango by-product added to the elephant grass silage. This decrease in the DM apparent digestibility may have been associated to the increase in the EE contents with the addition of mango byproduct. According to Palmquist (1991) increase in EE contents in the diet can hamper the digestibility of the fibrous fraction.

Adding mango by-product did not influence $(\mathrm{P}<0.05)$ the OM digestibility of the silages whose means were $51.74 \pm 4.82 \%$. Organic matter indicates the energetic value of the foodstuff, which is why there were no differences in the TDN values of the silages.

Including mango by-product in elephant grass silage reduced the CP digestibility by 1.23 percentage point. As the CP contents and nitrogen linked to the cell wall (NIDN and NIDA) practically did not alter with the addition of mango by-product, it is possible that other factors influenced the apparent CP digestibility. Thus more information should be collected about the mango byproduct, especially regarding the tannin contents of this material. According to Van Soest (1994) high tannin content is one of the main limiting factors to using byproducts from fruit processing.
Adding mango by-product to elephant grass silage reduced linear $(\mathrm{P}<0.05)$ the NDF and ADF digestibility. For each $1 \%$ mango by-product in the elephant grass silage, there was a reduction of 0.45 and 0.83 percentage point in the NDF and ADF digestibility, respectively. Rogério (2005) observed a reduction in NDF digestibility when by-product from Caribbean cherry processing was added to diets based on elephant grass. According to this author, the lignin content in the Caribbean cherry by-product was responsible for the reduction in the NDF and ADF digestibility.

The EE digestibility increased $(\mathrm{P}<0.01)$ with the addition of the mango by-product to the silage, with an increase of 1.49 percentage point for each $1 \%$ mango by-product added to the elephant grass silage. Bernardino et al. (2003) assessed elephant grass silage with the addition of coffee hulls and obtained a higher value with an average of $79.10 \%$.

The addition of mango by-product to elephant grass silage did not influence the digestibility of the total carbohydrates (52.62 \pm 5.48 ), nonfibrous carbohydrates (79.64 \pm 17.77$)$ or the total nutrient digestibility (50.28 \pm $4.01 \%)$. The reduction in the digestibility of the CP, NDF and ADF had direct implication in the quality of the silage containing mango by-product. Even with the NFC contents, the most digestible component of the foodstuff, rising from $4.67 \%$ in the untreated elephant grass diets to $12.08 \%$ in those with $16 \%$ mango by-product, the energetic value of the silage (TDN) did not alter.

Linear reduction was observed $(\mathrm{P}<0.01)$ for the nitrogen balance (NB) with the addition of mango by-product. For each $1 \%$ of mango by-product included, there was a $0.06 \mathrm{~g}$ /day reduction in the retained nitrogen. The reduction in the nitrogen balance may have been associated to the low digestibility of the crude protein and also to the low energy availability for the ruminal microorganisms. As the TDN values were relatively low (50.28\%) there may have been

Table 3 - Apparent digestibilities of total digestible nutrients and nitrgoen balance in sheep fed elephant grass silages containing mango by-product

\begin{tabular}{|c|c|c|c|c|c|c|c|c|}
\hline \multirow[t]{2}{*}{ Nutrient } & \multicolumn{5}{|c|}{ Level of mango by-product (\%) } & \multirow[t]{2}{*}{ Regression } & \multirow[t]{2}{*}{$\mathrm{R}^{2}$} & \multirow[t]{2}{*}{ CV $(\%)$} \\
\hline & 0 & 4 & 8 & 12 & 16 & & & \\
\hline Dry matter (\%) & 51.19 & 51.83 & 52.24 & 47.88 & 43.78 & $\widehat{Y}=53.14-0.47 X^{*}$ & 0.18 & 10.41 \\
\hline Organic matter (\%) & 52.68 & 52.75 & 55.78 & 50.47 & 47.04 & $\widehat{\mathrm{Y}}=51.74 \pm 4.82$ & - & 9.32 \\
\hline Crude protein (\%) & 38.65 & 40.91 & 31.63 & 26.02 & 19.98 & $\widehat{\mathrm{Y}}=41.88-1.23 \mathrm{x} * *$ & 0.41 & 27.71 \\
\hline Ether extract (\%) & 52.26 & 52.94 & 54.96 & 47.14 & 46.24 & $\hat{\mathrm{Y}}=48.71+1.49 \mathrm{x}^{* *}$ & 0.39 & 16.99 \\
\hline Neutral detergent fiber (\%) & 51.12 & 48.34 & 51.37 & 40.27 & 38.52 & $\widehat{\mathrm{Y}}=52.58-0.83 \mathrm{x} * *$ & 0.47 & 10.89 \\
\hline Acid detergent fiber (\%) & 46.14 & 55.36 & 64.27 & 67.42 & 69.87 & $\widehat{\mathrm{Y}}=48.71+1.49 \mathrm{x} * *$ & 0.39 & 16.99 \\
\hline Total carbohydrates (\%) & 54.07 & 53.58 & 57.13 & 51.36 & 46.94 & $\widehat{Y}=52.62 \pm 5.48$ & - & 10.43 \\
\hline Non-fibrous carbohydrates (\%) & 91.43 & 56.51 & 80.45 & 84.42 & 85.37 & $\widehat{Y}=79.64 \pm 17.77$ & - & 22.31 \\
\hline $\begin{array}{l}\text { Total digestible nutrients (\%) } \\
\text { Nitrogen blanace (g/day) }\end{array}$ & $\begin{array}{r}48.01 \\
0.82\end{array}$ & $\begin{array}{r}48.68 \\
0.92\end{array}$ & $\begin{array}{l}53.26 \\
-0.05\end{array}$ & $\begin{array}{r}50.26 \\
0.30\end{array}$ & $\begin{array}{l}51.21 \\
-0.14\end{array}$ & $\begin{array}{l}\hat{Y}=50.28 \pm 4.01 \\
(B N+1)(v)=1.87-0.06 x^{* *}\end{array}$ & 0.30 & $\begin{array}{r}7.97 \\
38.57\end{array}$ \\
\hline
\end{tabular}

*5 \% significance, $* * 1 \%$ significance.

$\mathrm{R}^{2}=$ coefficient of determination; $\mathrm{CV}=$ coefficient of variation. 
energy deficiency in the ruminal environment that damaged the microbial protein synthesis. However, there were no statistical differences for the TDN intakes (Table 2), the absolute values decreased from $24.35 \mathrm{~g} / \mathrm{kg} \mathrm{PV}^{0.75}$ for the animals fed untreated elephant grass silage to $18.38 \mathrm{~g} / \mathrm{kg}$ $\mathrm{PV}^{0.75}$ for the animals fed on silage containing $12 \%$ mango by-product.

The lower availability of nitrogen compounds in fruit by-products has been commented by Van Soest (1994) and some authors in Brazil. Reduction in nitrogen retention was observed by Dantas Filho et al. (2007) when dried cashew pulp was added to sheep diets. These authors argued that high tannin levels may have reduced the nitrogen available in the ruminal environment. Rogério (2005) also observed that the effective degradability of the cashew by-product, considering $5 \%$ passage rate, was only $25.81 \%$, almost half the degradability observed for elephant grass.

\section{Conclusions}

The addition of the by-product from mango processing at elephant grass ensilage, although it may improve the chemical composition, did not improve the nutritive value of the silage, leading to the reduction in intake and digestibility of some nutrients. Thus the mango by-product may be used at elephant grass ensilage only to alter the fermentation process, because it does not improve the nutritive value of the silage.

\section{References}

ANDRADE, J.B.; LAVEZZO, W. Aditivos na ensilagem do capimelefante. III. Valor nutritivo e consumo voluntário e digestibilidade aparente em ovinos. Pesquisa Agropecuária Brasileira, v.33, n.12, p.2015-2023, 1998.

BERNARDINO, F.S.; GARCIA, R.; SOUZA, A.L. et al. Consumo e digestibilidade de nutrientes de silagens de capim-elefante contendo casca de café, em ovinos. In: REUNIÃO ANUAL DA SOCIEDADE BRASILEIRA DE ZOOTECNIA, 40., 2003, Santa Maria. Anais... Santa Maria: Sociedade Brasileira de Zootecnia/ Gmosis, 2003. (CD-ROM).

BERNARDINO, F.S.; GARCIA, R.; ROCHA, F.C. et al. Produção e características do efluente e composição da silagem de capimelefante contendo diferentes níveis de casca de café. Revista Brasileira de Zootecnia, v.34, n.6, p.2185-2291, 2005.

DANTAS FILHO, L.A.; LOPES, J.B.; VASCONCELOS, V.R.. et al. Inclusão de polpa de caju desidratada na alimentação de ovinos: desempenho, digestibilidade e balanço de nitrogênio. Revista Brasileira de Zootecnia, v.36, n.1, p.147-154, 2007.

FARIA, V.P.; TOSI, H.; GODOY, C.R.M. Polpa de laranja fresca e seca como aditivos para a ensilagem do capim-elefante Napier (Pennisetum purpureum Schum.). O Solo, v.64, n.1, p.41-47, 1972.

FERREIRA, A.C.H.; NEIVA, J.N.M.; RODRIGUEZ, N.M. et al. Avaliação nutricional do subproduto da agroindústria de abacaxi como aditivo de silagem de capim-elefante. Revista Brasileira de Zootecnia, v.38, p.223-229, 2009.

GOMIDE, J.A. Formação e utilização de capineira de capim-elefante. In: CARVALHO, M.M.; BOTREL, M.A.; MARTINS, C.E. (Eds.) Capim-elefante: produção e utilização. Brasília: EmbrapaSP; Juiz de Fora: EMBRAPA-CNPGL, 1997. p.79-112.

GOMIDE, J.A.; CHRISTMAS, E.P.; GARCIA, R. et al. Competição de gramíneas forrageiras para corte em um latossolo vermelho distrófico sob vegetação de cerrado do Triângulo Mineiro. Revista Brasileira de Zootecnia, v.3, n.2, p.191-209, 1974.

HALL, M.B. Recent advanced in non-ndf carbohydrates for the nutrition of lactating cows. In: SIMPÓSIO INTERNACIONAL EM BOVINOS DE LEITE: Novos conceitos em nutrição, 2. 2001, Lavras. Anais... Lavras: Universidade Federal de Lavras, 2001. p.139-148.

LAVEZZO, W. Silagem de capim elefante. Informe Agropecuário, v.11, n.132, p.50-57, 1985

McDONALD, P. The biochemistry of silage. New York: John Willey \& Sons, 1981. 226p.

MIZUBUTI, I.Y.; RIBEIRO, E.L.A.; ROCHA, M.A. et al. Consumo e digestibilidade aparente das silagens de milho (Zea mays L.), sorgo (Sorghum bicolor (L.) Moench) e girassol (Helianthus annuus L.). Revista Brasileira de Zootecnia, v.31, n.1, p.267-272, 2002.

NEIVA, J.N.M.; NUNES, F.C.S.; CÂNDIDO, N.M.R. et al. Valor nutritivo de silagens de capim-elefante enriquecidas com subproduto do processamento do maracujá. Revista Brasileira de Zootecnia, v.35, n.4, p.1843-1849, 2006.

NUSSIO, L.G.; PAZIANI, S.F.; NUSSIO, C.M.B. Ensilagem de capins tropicais. In: REUNIÃO ANUAL DA SOCIEDADE BRASILEIRA DE ZOOTECNIA, 39., 2002, Recife. Anais... Recife: Sociedade Brasileira de Zootecnia, 2002. p.60-90.

PALMQUIST, D.L. Influence of source and amount of dietary fat on digestibility in lactating cows. Journal of Dairy Science, v.74, p.1354-1360, 1991.

PALMQUIST, D.L. Suplementação de lipídeos para vacas em lactação. In: SIMPÓSIO SOBRE PRODUÇÃO ANIMAL, 1989, Piracicaba. Anais... Piracicaba: Fundação de Estudos Agrários Luiz de Queiroz, 1989. p.11-26.

REIS, J.; PAIVA, P.C.A.; TIESENHAUSEN, I.M.E.V.V. et al. Composição química, consumo voluntário e digestibilidade de silagens de resíduos do fruto de maracujá (Passiflora edulis Sims f. flavicarpa) e de capim-elefante (Pennisetum purpureum, Schum.) cv. Cameroon e suas combinações. Ciência Agrotécnica, v.24, n.1, p.213-224, 2000.

ROGÉRIO, M.C.P. Valor nutritivo de resíduos da indústria processadora de frutas utilizados na alimentação de ovinos. 2005. 433f. Tese (Doutorado em Ciência Animal) - Universidade Federal de Minas Gerais, Belo Horizonte.

SÁ, C.R.L.; NEIVA, J.N.M.; GONÇALVES, J.S. et al. Composição bromatológica e características fermentativas de silagens de capim elefante (Pennisetum purpureum Schum.) com níveis crescentes de adição do subproduto da Manga (Mangifera indica L.). Revista Ciência Agronômica, v.38, n.2, p.199-203, 2007.

SILVA, D.J.; QUEIROZ, A.C. Análises de alimentos: métodos químicos e biológicos. 2.ed. Viçosa, MG: Universidade Federal de Viçosa, 2002. 165p.

SILVA, J.F.C.; LEÃO, M.I. Fundamentos de nutrição dos ruminantes. Piracicaba: Livro Ceres, 1979. 380p.

SILVEIRA, A.C.; LAVEZZO, W.; SILVEIRA FILHO, S. et al. Consumo de silagens de capim-elefante (Pennisetum purpureum Schum.) submetidas a diferentes tratamentos. Revista Brasileira de Zootecnia, v.9, n.2, p.306-320, 1980.

SNIFFEN, C.J.; O'CONNOR, J.D.; VAN SOEST, P.J. A net carbohydrate and protein system for evaluating cattle diets: II. carbohydrate and protein availability. Journal of Animal Science, v.70, n.11, p.3562-3577, 1992.

SOUZA, V.G.; PEREIRA, O.G.; MORAES, S.A. et al. Valor nutritivo de silagens de sorgo. Revista Brasileira de Zootecnia, v.32, n.3, p.753-759, 2003. 
STATISTICAL ANALYSES SYSTEM - SAS. User’s guide. Cary: SAS Institute, 2001. 1028p.

VAN SOEST, P. J. Nutritional ecology of the ruminant. 2.ed., Ithaca, New York: Cornell University Press, 1994. 476p.

VILELA, D.; CARNEIRO, J.C. Ensilagem do excedente de pasto: uma alternativa para o manejo. In: SIMPÓSIO SOBRE MANEJO ESTRATÉGICO DE PASTAGENS, 1., Viçosa, MG, 2002. Anais... Viçosa, MG: Universidade Federal de Viçosa, 2002. p.331-350.
WILKINS, R.J.; HUTCHINSON, K.J.; WILSON, R.F. et al. The voluntary intake of silage by sheep. I. Interrelationships between silage composition and intake. Journal of Agricultural Science, v.77, n.3, p.531-537, 1971.

WILKINSON, J.M. Silage made from tropical and temperate crops. 2. Techniques for improving the nutritive value of silage. World Animal Review, v.46, n.1, p.35-40, 1983. 